\title{
Ki-1 Large Cell Lymphoma with Regressing Lesions in a Child
}

\author{
Achiléa Lisboa Bittencourt, M.D., ${ }^{* \dagger}$ Nubia Mendonça, M.D.,* \\ Luiz Antonio Rodrigues de Freitas, M.D., $\dagger \neq$ and Bertram Schnitzer, M.D. $\S$ \\ *Department of Pathology and Pediatric Oncology, Hospital Martagão Gesteira, Salvador, Bahia, Brazil, \\ $\dagger$ Department of Pathology, Federal University of Bahia, Brazil, $\neq$ Centro de Pesquisas Gonçalo Moniz \\ (Fundaçäo Oswaldo Cruz), Salvador, Bahia, Brazil, and \$Department of Pathology, University of \\ Michigan, Ann Arbor, Michigan
}

\begin{abstract}
An 8-year-old boy was seen with a cutaneous $\mathrm{Ki}-1$ anaplastic, large cell lymphoma with multiple lesions. Some of the lesions showed spontaneous regression. During more than seven years of disease no systemic involvement was observed, but recurrent, self-healing lesions did appear. Histopathologic examination of five lesions revealed a variety of findings, from an inflammatory infiltrate to a highly anaplastic pattern. The neoplastic cells expressed $\mathrm{Ki}-1$ and leukocyte common antigens. UItrastructurally, those cells showed ruffled indentations. The differential diagnosis includes microvillous malignant lymphoma. The patient has had a four-year follow-up without relapses.
\end{abstract}

In 1985 Stein et al (1) described an anaplastic large cell lymphoma (ALCL) that expressed a Hodgkin disease-associated antigen, $\mathrm{Ki}-1$, an entity previously misdiagnosed as malignant histiocytosis or anaplastic carcinoma. The Ki-1 ALCL expresses $\mathrm{T}$ cell or, less frequently, B cell antigens, although occasionally neither antigen is expressed. Since that first description, approximately 170 cases have been published (2-21), half of which occurred in children $(2,4,5,7,9,11,13,15,16,20)$.

Peripheral lymph nodes constitute the most frequent primary site of the tumor, but the skin, mediastinal lymph nodes, and stomach may also be involved in initial disease. The prognosis is more favorable when the skin is the primary site $(3,11-$ $14,18)$. The cutaneous lesions are represented by solitary or multiple nodules and, less frequently, infiltrated plaques or tumors. In 1986 Kadin et al (11) described six children with Ki-1 ALCL with peripheral lymphadenopathy, three of whom had regressing skin nodules. Follow-up was limited, however, and biopsies were performed in just one lesion from each patient.

We cared for a child with cutaneous Ki-1 ALCL with regressing skin lesions for seven years. Histopathologic examination was performed on five lesions representing different stages of development.

\section{CASE REPORT}

A 6-year-old boy was admitted in July 1987 with a four-year history of spontaneously regressing cutaneous nodules on the abdomen. Two months before admission three new lesions had appeared in the same area, two of which had gradually increased in size and shown no evidence of involution. The child had no other complaints. The only remarkable

Address correspondence to Achiléa L. Bittencourt, M.D., Department of Pathology, Hospital Martagão Gesteira, Rua José Duarte, 114, Tororó, 40.050, Salvador, Bahia, Brasil. 


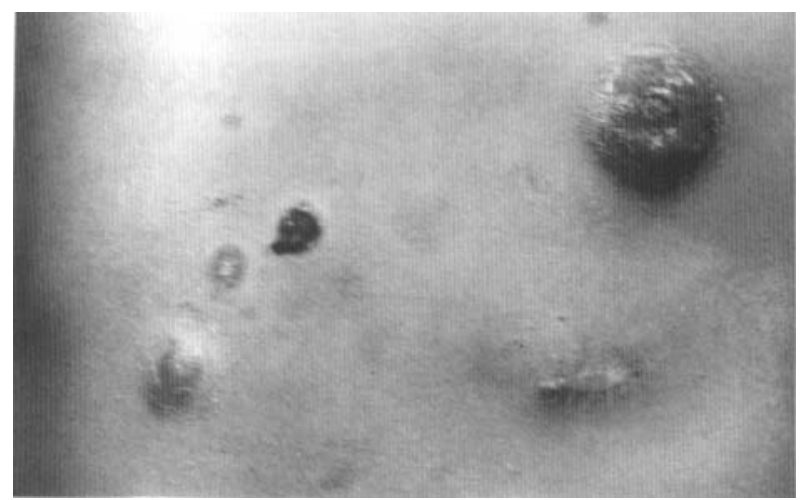

Figure 1. Two lesions, one surgical scar, and many small hyperchromic scars corresponding to involuted lesions.

physical findings were three abdominal nodules with a scaly, erythematous surface, measuring 3.3 $\times 3.3 \mathrm{~cm}, 2.0 \times 2.0 \mathrm{~cm}$, and $0.7 \times 0.7 \mathrm{~cm}$, respectively (Fig. 1). Slightly depressed scars were seen on the surrounding skin. Physical examination revealed no other abnormalities.

The larger lesion was excised and a diagnosis of malignant fibrous histiocytoma was made. After this diagnosis the other two lesions were completely excised. Laboratory findings, bone marrow morphology, and a chest roentgenogram were unremarkable. No therapy was undertaken.

Ten months later the patient had a relapse on the surgical scar of the larger nodule that did not regress. At this time clinical and laboratory evaluation showed no other abnormalities. The lesion was excised and submitted for histopathologic study. Due to the diagnosis of Ki-1 ALCL, the patient underwent chemotherapy according to the LSA2-L2 protocol (22) as follows: induction phase-intravenous cyclophosphamide with radiation therapy, prednisone plus vincristine, intrathecal methotrexate, and intravenous daunomycin; consolidation phase-intravenous cytosine arabinoside and oral thioguanine, intravenous L-asparaginase, intrathecal methotrexate, and intravenous $\mathrm{BCNU}[1,3-$ bis(2-chloroethyl)-1-nitrosourea]; and maintenance phase-five-day cycles of thioguanine, cyclophosphamide, hydroxyurea, daunomycin, methotrexate, $\mathrm{BCNU}$, arabinosylcytosine, and vincristine followed by intrathecal methotrexate. This regimen continued for one year. Two weeks prior to conclusion of treatment the child developed five erythematous, papulonodular lesions on the chest, measuring from 1.0 to $0.2 \mathrm{~cm}$, that disappeared completely in a few weeks. One of those lesions was excised and submitted for histopathologic examination. No other lesions developed. At the last evaluation in September 1991, no other abnormalities were observed.

\section{LABORATORY STUDIES}

Formalin-fixed tissue was processed routinely, embedded in paraffin, and stained with hematoxylin and eosin.

\section{Histopathologic Studies}

The histologic appearance of the three initial lesions was not uniform. The largest lesion exhibited an extensive pleomorphic infiltrate entirely replacing the dermis and subcutis. The infiltrate was predominantly composed of large, highly atypical, mononuclear and polynuclear cells with marked nuclear atypia and an abundant amphophilic cytoplasm (Fig. 2). Frequently the nuclei were indented and eccentrically placed in the cytoplasm, which had a prominent paranuclear halo. Multinucleated cells were present, some of which exhibited horseshoe and wreathlike disposition of nuclei. Chromatin tended to be granular and evenly distributed. A prominent nucleolus was generally observed. Mitotic figures, including atypical figures, were very common.

The medium-size lesion showed a diffuse infiltration replacing the dermis and part of the subcutis. The infiltrate was composed of small lymphocytes, histiocytes, polymorphonuclear leukocytes, and many mononuclear and polynuclear atypical cells with frequent mitosis. Cellular pleomorphism was less marked.

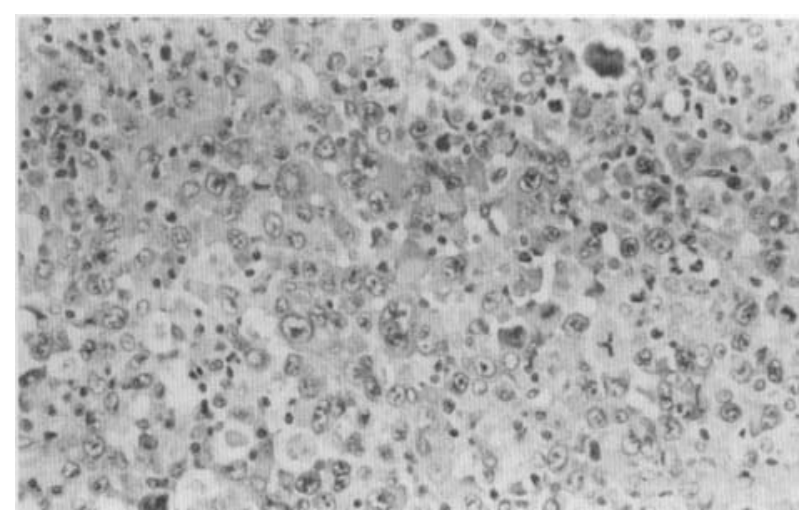

Figure 2. Large mononuclear cells with oval or reniform nuclei with prominent nucleoli and abundant $c y-$ toplasm. (Hematoxylin \& eosin; magnification $400 \times$.) 


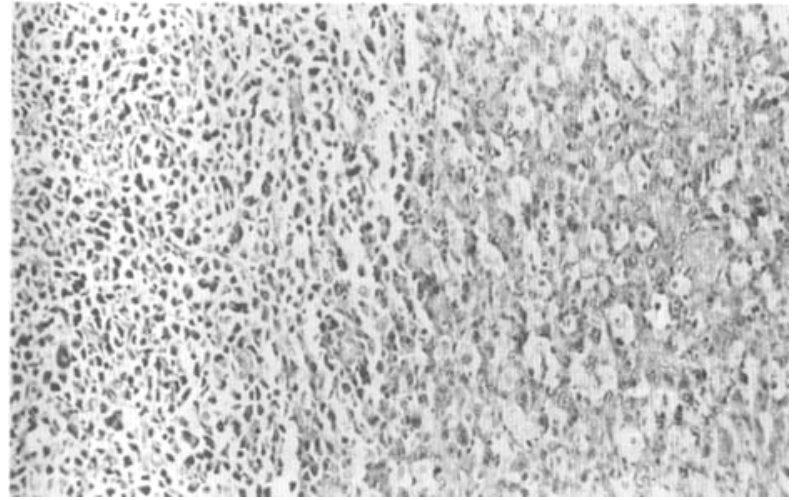

Figure 3. Section from the recurrent lesion. At left is a highly anaplastic infiltration with giant cells; at right are cohesive neoplastic cells with pale-staining macrophages among them. (Hematoxylin \& eosin; magnification $160 \times$.)

The smaller lesion had a benign appearance, consisting of a diffuse infiltrate, with small lymphocytes and histiocytes replacing the dermis and the superficial part of the subcutis. Granulation-like tissue was observed on the superficial part of the lesion. Areas of hemorrhage and fibrosis were also seen.

The recurrent lesion was the most pleomorphic. It was almost entirely composed of pleomorphic cells with abundant eosinophilic cytoplasm. The neoplastic cells at the edge of the lesion in the subcutis appeared cohesive and had pale-staining macrophages among them, imparting a "starry-sky" pattern (Fig. 3). Giant tumor cells and mitosis were frequently seen. Infiltration by polymorphonuclear leukocytes was present only in small foci. Sparse binucleated cells resembling Reed-Sternberg cells were also observed. In all lesions the epidermis showed mild to moderate acanthosis, but no epidermotropism of neoplastic cells was observed. The last biopsied lesion showed an inflammatory infiltrate only.

\section{Immunohistochemical Studies}

Formalin-fixed and paraffin-embedded sections of the first large nodule were immunostained using commercially available antibodies (Table 1) and the avidin-biotin immunoperoxidase method (20). Biotinolated horse antimouse antibody and avidinbiotin peroxidase complex reagents were obtained from Vector Laboratories (Burlington, CA). Sections of the recurrent lesion were also tested with leukocyte common antigen (LCA) and HAM-56. Ber-H2 (CD30) and LCA (CD45) antibodies stained
TABLE 1. Panel of Antibodies

\begin{tabular}{|c|c|c|}
\hline Antibodies & Source & Major Specificity \\
\hline $\begin{array}{l}\text { Leukocyte common } \\
\text { antigen }\end{array}$ & $\mathrm{D}$ & Leukocytes \\
\hline Ber-H2 (CD 30) & $\mathrm{D}$ & $\begin{array}{l}\text { Ki-1 antigens, found on } \\
\text { Reed-Sternberg cells, } \\
\text { some large-cell } \\
\text { lymphomas, activated } \\
\text { lymphoid cells }\end{array}$ \\
\hline $\begin{array}{l}\text { Epithelial membrane } \\
\text { antigen }\end{array}$ & $\mathrm{D}$ & $\begin{array}{l}\text { Epithelial cells, plasma } \\
\text { cells, some } \\
\text { lymphomas }\end{array}$ \\
\hline UCHL1 (CD45RO) & $\mathrm{D}$ & $\mathrm{T}$ cells \\
\hline $\mathrm{L}-26$ & $\mathrm{D}$ & B cells \\
\hline Leu-M1 (CD15) & $\mathrm{BD}$ & $\begin{array}{l}\text { Myeloid, monocytic, } \\
\text { Reed-Sternberg cells }\end{array}$ \\
\hline HAM-56 (MA-935) & $\mathrm{E}$ & $\begin{array}{l}\text { Monocytes, } \\
\text { macrophages }\end{array}$ \\
\hline
\end{tabular}

$\mathrm{D}=$ Dako Corporation $; \mathrm{BD}=$ Beckton Dickson; $\mathrm{E}=$ Enzodiagnostiks.

all the neoplastic cells (Fig. 4). The other antibodies were negative.

\section{Ultrastructural Studies}

Small skin samples were immediately immersed in $2 \%$ glutaraldehyde in $0.1 \mathrm{M}$ sodium cacodylate

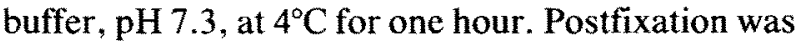
in $1 \%$ osmium tetroxide in $0.15 \mathrm{M}$ sodium cacodylate buffer, $\mathrm{pH} 7.3$, at $4^{\circ} \mathrm{C}$ for one hour. Dehydration was performed in graded acetone. Tissue fragments were included in Epon 812 resin. Blocks were trimmed and semithin sections were stained with azur II-toluidine blue. Ultrathin sections were contrasted with uranyl acetate and lead citrate. Sections were evaluated using a transmission electron microscope (Zeiss model EM-109) at $50 \mathrm{kV}$.

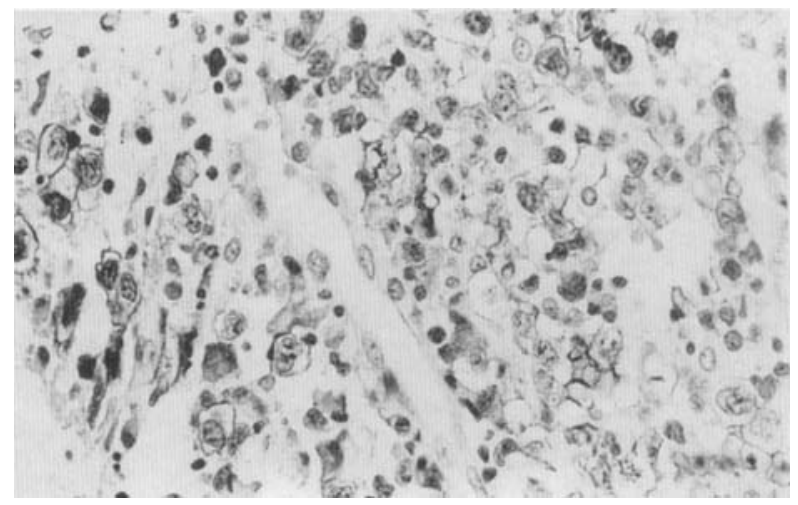

Figure 4. Ki-1-positive anaplastic cells (anti-Ki-1 paraffin section, immunoperoxidase procedure). (Magnification $400 \times$.) 
The neoplastic cells had abundant cytoplasm with many polyribosomes, few profiles of rough endoplasmic reticulum, variable numbers of mitochondria, and a small Golgi apparatus. Few neoplastic cells showed lysosomes. The cells frequently exhibited short cytoplasmic processes (Fig. 5) that occasionally interdigitated with other similar cells. The nuclei showed great variation in size and shape; sometimes nuclear indentations were present. The heterochromatin was usually present as a narrow rim adjacent to the inner nuclear membrane. One or two prominent nucleoli were present in the neoplastic cells. Frequently, atypical mitotic figures were seen. Phagocytosis of dead cells by macrophage-like cells was observed.

\section{DISCUSSION}

This patient had a primary cutaneous Ki-1 ALCL with an indolent clinical course characterized by regression of the lesions and a seven-year evolution without involvement of other organs.

A similar clinicopathologic picture was described in 1982 as regressing atypical histiocytosis (23). Up to now 11 cases of this entity have been described in the literature $(24,25)$. Immunologic phenotyping and rearrangement of $T$ cell receptor and chain genes suggested that regressing atypical histiocytosis represents an ALCL (26). In our patient the positivity of this tumor for LCA and $\mathrm{Ki}-1$ antigens, and the lack of immunoreactivity for HAM-56, a histiocytic marker, permitted the differential diagnosis of regressing atypical histiocytosis and malignant histiocytosis.

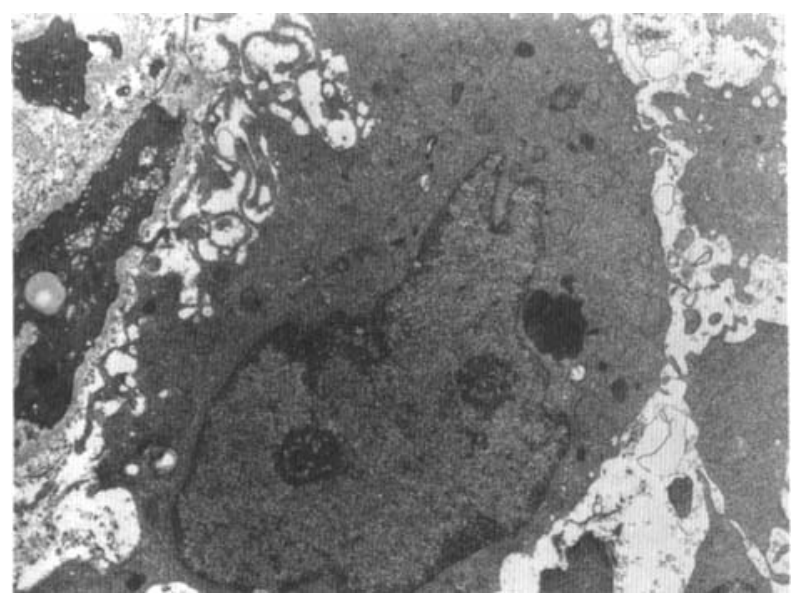

Figure 5. Electron microscopy demonstrates a cell with ruffled cytoplasmic membrane and indented nucleus. (Magnification 12,000x.)
Because of the presence of Reed-Sternberg-like cells in Ki-1 ALCL, the differential diagnosis with Hodgkin disease with skin involvement must be made with caution. Hodgkin disease limited only to the skin has been very rarely reported $(27,28)$, however, and some authors doubt its existence $(29,30)$. In debated cases, no immunohistochemical studies were performed, and probably they represented lymphomatoid papulosis (LP) or even ALCL (2830 ). In addition, the marked pleomorphism, the high mitotic rate, and the cohesive pattern of the neoplastic cells observed in our patient are not generally observed in Hodgkin disease (19), allowing a diagnosis of $\mathrm{Ki}-1 \mathrm{ALCL}$.

Lymphomatoid papulosis is also characterized by self-healing skin lesions, and consists of a mixed infiltration of inflammatory and anaplastic Ki-1positive cells similar to those of ALCL (31-33). However, in LP the lesions are smaller and more widespread, and show epidermotropism of the anaplastic cells. Those features have not been described in cutaneous Ki-1 ALCL. Considering the similarities between the disorders, and the fact that an association of inflammatory and neoplastic lesions (as described in LP) was also observed in our patient, we may speculate that regressing $\mathrm{Ki}-1$. ALCL represents an intermediate entity between LP and cutaneous $\mathrm{Ki}-1$ ALCL. Unfortunately, in the other four published cases of cutaneous regressing $\mathrm{Ki}-1 \mathrm{ALCL}(11,26)$ the association of inflammatory and neoplastic features was not referred to, possibly because only one lesion of each patient was examined.

The diagnosis of this type of highly anaplastic cutaneous lymphoma must be made on the basis of $\mathrm{Ki}-1$ reactivity to distinguish it from other highly malignant tumors, some of them metastatic to the skin. Negativity to epithelial and histiocytic markers and positivity for LCA and $\mathrm{Ki}-1$ antigens make the diagnosis possible. One epithelial membrane antigen that is sometimes expressed by $\mathrm{Ki}-1$ ALCL cells is EMA $(10,20)$, but EMA was not observed in this patient. Also, no reactivity was observed with $T$ and $B$ cell markers. We cannot exclude the possibility that failure to demonstrate these antigens was the result of antigen loss due to tissue fixation and paraffin embedding.

The neoplastic cells observed in our patient had ultrastructurally ruffled cytoplasmic membranes and reniform nuclear indentations, aspects that suggest histiocytic differentiation, according to Burns et al (6). However, the organelles were not prominent, lysosomes were scarce, and phagocytosis by 
tumor cells was not observed. Furthermore, immunolabeling with HAM-56, a monoclonal antibody considered to recognize histiocytes, was negative. Cytoplasmic projections have been observed in around $20 \%$ of cases of Ki-1 ALCL (34). Microvillous lymphomas have a similar ultrastructural appearance, but these tumors are Ki-1 negative (34).

Undoubtedly, cutaneous Ki-1 ALCL has a better prognosis than Ki-1 ALCL of extracutaneous localization and other large cell lymphomas. The experience with $\mathrm{Ki}-1 \mathrm{ALCL}$ with self-healing tendency was limited to four cases, three of them associated with nodal involvement $(11,24)$. All were treated with radiotherapy and/or chemotherapy. Those with nodal lesions had relapses but were alive 4 to 30 months after diagnosis. The patient without nodal involvement received radiotherapy only and was well two years after diagnosis, with no relapse (24). Our patient has had no relapse four years after treatment, indicating a good response to chemotherapy. However, as experience with cutaneous $\mathrm{Ki}-1$ ALCL with regressing lesions is limited, it is difficult to delineate the best therapeutic approach.

\section{REFERENCES}

1. Stein H, Mason DY, Gerdes I. The expression of the Hodgkin's disease associated antigen $\mathrm{Ki}-1$ in reactive and neoplastic lymphoid tissue: evidence that ReedSternberg cells and histiocytic malignancies are derived from activated lymphoid cells. Blood 1985;66: $848-858$.

2. Agnarsson BA, Kadin ME. Ki-1 positive large cell lymphoma. Am J Surg Pathol 1988;12:264-274.

3. Berti E, Gianotti R, Alessi E. Primary anaplastic large cell lymphoma of the skin. Dermatologica 1989; 178:225-227.

4. Bitter MA, Franklin WA, Larson RA, et al. Morphology in $\mathrm{Ki}-1$ (CD 30)-positive non-Hodgkin's lymphoma is correlated with clinical features and the presence of a unique chromosomal abnormality, t(2;5) (p23;q35). Am J Surg Pathol 1990;14:305-316.

5. Buscky P, Feller AC, Beck JD, et al. Zur Frage der Definition der malignen Histiozytose und des groszelligen anaplastichen (Ki-1) Lymphoma in Kindesalter. Klin Paediatr 1989;201:233-236.

6. Burns BF, Cripps C, Dardick I. A case of a $\mathrm{Ki}-1$ large cell anaplastic lymphoma with ultrastructural features. Hum Pathol 1989;20:393-396.

7. Carbone A, Gloghini A, De Re V, Tamaro P, Boiocchi M, Volpe R. Histopathologic, immunophenotypic, and genotypic analysis of $\mathrm{Ki}-1$ anaplastic large cell lymphomas that express histiocyte-associated antigens. Cancer 1990;66:2547-2556.

8. Chan JKC, Buchanan R, Fletcher CDM. Sarcomatoid variant of anaplastic Ki-1 lymphoma. Am J Surg Pathol 1990;14:983-988.
9. Fujimoto J, Hata J, Ishii E, et al. Ki-1 lymphomas in childhood: immunohistochemical analysis and the significance of epithelial membrane antigen (EMA) as a new marker. Virchows Arch 1988;412:307-314.

10. Hall PA, D'Ardenne AJ, Stansfeld AG. Paraffin section immunohistochemistry. II. Hodgkin's disease and large cell anaplastic (Ki-1) lymphoma. Histopathology 1988;13:161-169.

11. Kadin ME, Sako D, Berliner N. Childhood Ki-1 lymphoma presenting with skin lesions and peripheral lymphadenopathy. Blood 1986;68:1042-1049.

12. Kaudewitz P, Stein H, Dellenbach F, et al. Primary and secondary cutaneous $\mathrm{Ki}-1+(\mathrm{CD} \mathrm{30+)}$ anaplastic large cell lymphomas. Am J Pathol 1989;135:359367.

13. Leake J, Kellie SI, Pritchard J, Chessells JM, Ridson RA. Peripheral T-cell lymphoma in childhood. A clinicopathological study of six cases. Histopathology 1989;14:255-268.

14. Lindholm JS, Barron DR, Williams ME. Ki-1 positive cutaneous large cell lymphoma of T-cell type: report of an indolent subtype. J Am Acad Dermatol 1989;20:342-348.

15. Mason DY, Bastard C, Rimokh R, et al. CD 30positive large cell lymphomas (Ki-1 lymphoma) are associated with a chromosomal translocation involving 5q35. Br J Haematol 1990;74:161-168.

16. Oka $K$, Mori $N$, Kojima $M$, Iijima $T$, Hanada $T$, Tsuchida M. Childhood Ki-1 lymphoma. A report of two cases. Arch Pathol Lab Med 1989;113:998-1002.

17. Pileri S, Mazza R, Zinzani PL, Poggi S, Poletti G, Falini B. Ki-1 lymphoma and Hodgkin's disease. Haematologica 1989;74:333-334.

18. Ralfkiaer E, Bosq J, Gatter KC, et al. Expression of a Hodgkin and Reed-Sternberg cell associated antigen (Ki-1) in cutaneous lymphoid infiltrates. Arch Dermatol Res 1987;279:285-292.

19. Rosso R, Paulli M, Magrini V, et al. Anaplastic large cell lymphoma, CD $30 \backslash \mathrm{Ki}-1$ positive, expressing the CD 15Leu M1 antigen. Virchows Arch 1990;416: 229-235.

20. Schnitzer B, Roth MS, Hyder DM, Ginsburg D. Ki-1 lymphomas in children. Cancer 1988;61:1213-1221.

21. Sterry W, Korte B, Schubert C. Pleomorphic T-cell lymphoma and large-cell anaplastic lymphoma of the skin. Am J Dermatopathol 1989;11:112-123.

22. Wollner $\mathbf{N}$, Lieberman PH, Exelby $\mathbf{P}$, et al. NonHodgkin's lymphoma in children: results of treatment with LSA2-L2 protocol. $\mathrm{Br} J$ Cancer 1975;31(suppl II):337-342.

23. Flynn KJ, Dehner LP, Gajl-Peczalska, Dahl MV, Ramsay N, Wang N. Regressing atypical histiocytosis: a cutaneous proliferation of atypical neoplastic histiocytes with unexpectedly indolent biological behavior. Cancer 1982;49:959-970.

24. Headington JT, Roth MS, Schnitzer B. Regressing atypical histiocytosis: a review and critical appraisal. Semin Diagn Pathol 1987;4:28-37.

25. McCormick S, Stein KS, Nelligan D. Regressing atypical histiocytosis. Report of a case. Am J Dermatopathol 1984;6:259-263.

26. Headington JT, Roth MS, Ginsburg D, Lichter AS, 
Hyder D, Schnitzer B. T-cell receptor gene rearrangement in regressing atypical histiocytosis. Arch Dermatol 1987;123:1183-1187.

27. Szur L, Harrinson CV, Levene GM, Samman PD. Primary cutaneous Hodgkin's disease. Lancet 1970; 1016-1020.

28. White RM, Patterson JW. Cutaneous involvement in Hodgkin's disease. Cancer 1985;55:1136-1145.

29. Smith JL, Butler JJ. Skin involvement in Hodgkin's disease. Cancer 1980;45:354-361.

30. Lever WF, Schaumburg-Lever G. Histopathology of the skin. Philadelphia: JB Lippincott, 1990.
31. Valentino LA, Helwig EB. Lymphomatoid papulosis. Arch Pathol 1973;96:409-416.

32. Weimman VF, Ackerman AB. Lymphomatoid papulosis. Am J Dermatopathol 1981;3:129-163.

33. Sanchez NP, Pittelkow MR, Muller SA. The clinicopathologic spectrum of lymphomatoid papulosis: study of 31 cases. Am J Acad Dermatol 1983;8:81-94.

34. Kinney MC, Glick AD, Stein H, Collins RD. Comparison of anaplastic large cell $\mathrm{Ki}-1$ lymphomas and microvillous lymphomas in their immunologic and ultrastructural features. Am J Surg Pathol 1990;14: 1047-1060. 